\title{
A „NEMZETI PARK” KONCEPCIÓ TÉR- ÉS IDŐBELI VÁLTOZÁSAI
}

\author{
KŐSZEGI MARGIT - BOTTLIK ZSOLT - TELBISZ TAMÁS - MARI LÁSZLÓ \\ SPATIAL AND TEMPORAL CHANGES IN THE CONCEPT OF 'NATIONAL PARK'
}

\begin{abstract}
Our study presents the changes in the concept of the national park in space and time to Hungarian readers. It does this not only because the role of national parks in recreational activities in Hungary has been evaluated in recent decades, but also because of the change in the way we think about the environment around us and the frameworks created to protect nature. In our article, we present the appearance and practical implementation of the idea of the national park in the United States and then follow the expansion and internationalisation of the Yellowstone model in the world. We reveal the different social phenomena and responses behind this concept, and the changes that can be interpreted as the effects of the changes through modernisation. Our study serves as an introduction to our research, which discusses the situation of domestic national parks in an international context.
\end{abstract}

Keywords: national park, Yellowstone model, conservation, state control, preservation, protection, presentation

\section{Bevezetés}

A nemzeti parkok a 21. században is jelentôs aktorokként vannak jelen a világban. Ugyan az első́ nemzeti park létrehozása óta eltelt közel 150 év alatt jelentősen módosult jelentéstartalmuk, valamint szerepük és megítélésük, de a társadalom számára fóként a természettel, a környezettel való közvetlen kapcsolattartás helyszínét jelentik. A természet védelmének szimbólumaként tekintenek rájuk, ezért a rekreációs tevékenységek sorában látogatásuk előkelő helyet foglal el.

Magyarországon az első nemzeti parkok igen későn, az 1970-es években jöttek létre, az ENSZ égisze alatt múködő nemzetközi hálózat részeként. A pártállami diktatúra időszakában létrehozott természetvédelmi területek a rendszerváltást követően a hazai társadalomban is felértékelődtek. A globalizációval beköszöntő életmódváltozás, a természetvédelem diskurzusának kiteljesedése, valamint a globális klímaváltozás kérdéseinek hétköznapokban való megjelenése kiszorította az elmúlt évtizedekek nihilista gondolkodását, miközben a hazai turizmus állam által is támogatott felfutása a gyakorlatban is növelte a hazai nemzeti parkok jelentőségét.

A nemzeti park fogalma, eszméje, gyakorlati megvalósítása, valamint a hozzá kapcsolódó diskurzusok léte szervesen kötódik a modernitáshoz (GLENDINNING, M. 2003; LATOUR, B. 1999). Az életmód átalakulásával az elmúlt évszázadokban egyre inkább nőtt a távolság ember és természet között, a dichotómia mélyebb értelmet kapott (WEST, P. et al. 2006). A különbség/különbözőség érzete erőteljesebb lett, ami egyrészt a természet semmibe vételét, másrészt viszont a természet értékként való értelmezését is életre hívta. Ez utóbbi kapcsán merült fel a nemzeti parkok eszméje a 19. század végén.

Az ember és természet közötti távolsággal összefüggésben, ahogyan azt a park elnevezés is sugallja, a természettel való érintkezés már nem a mindennapok, hanem kifejezetten a pihenéssel eltöltött idô része lett. Minél inkább az épített környezetre korlátozódik a társadalom élete, annál inkább jelentkezik az igény a szabadidő természetben való eltöltésére. Ez azonban nem jelenti azt, hogy a modernitással együtt járó kényelmi szempontok nem számítanak elvárásnak a rekreációs tevékenységekben, ezért a természettel való találkozás 
is szervezett, ellenőrzött kereteket kívánt, aminek a nemzeti park már a kezdetektől eleget kívánt tenni. Természet és társadalom dichotómiájának sajátos határterülete ez (WILSHUSEN, P. et al. 2002), ami a trialektikus gondolkodásban (BERKI M. 2015) új értelmet nyer azáltal, hogy az éles elkülönülés helyett egy mindkét kategóriában értelmezhetô tér válik a nemzeti park eszméjében és gyakorlati kivitelezésében valósággá.

\section{A nemzeti parkok vizsgálatának elmélete és módszertana}

A 21. század embere számára Magyarországon, ahogy nemzetközi viszonylatban is a nemzeti park elnevezés közismert fogalmat, valós és ismert (sok esetben megtapasztalt) területet, speciális természetvédelmi szerepkört, valamint a hozzá kapcsolódó tevékenységeket takar. Mivel társadalmi konstrukcióról van szó, ezért értelmezése az idó és a tér függvényében folyamatosan változik. A nemzeti park eszméje és a megvalósítás folyamata mögött ugyanis időben és térben is eltérő diskurzusok vannak. Jelen tanulmányunk a nemzeti parkok alapításával és múködésével foglalkozó diskurzusok lényegi elemeit tárja fel diskurzuselemzés (SAID, E. W. 2000), illetve dekonstrukció (DERRIDA, J. 2014) segítségével. A nemzeti parkok társadalmi háttere kapcsán keletkező szövegek kontextusára helyezzük a hangsúlyt: a nemzeti parkok szerepével kapcsolatos különböző interpretációk feltárása mellett a történelmi-társadalmi beágyazottságé a főszerep.

Noha a hazai nemzeti parkok száma a rendszerváltás óta megduplázódott, társadalmi hatásuk vizsgálata a hazai tudományos közegben egyelőre csekély mértékben indult meg (pl. ExLER Sz. et al. 2003; SzALAI K.-SzILÁGYiZs. 2007). Kutatócsoportunk e hiányosságot igyekszik pótolni munkájával a hazai és külföldi nemzeti parkok összehasonlító vizsgálata révén, amelynek egyik fontos állomása a jelen munkában bemutatott diskurzuselemzés, aminek segítségével a nemzeti park értelmezését kívánjuk tágítani. A nemzeti parkok társadalmi hatásainak, illetve a különböző időszakra jellemző társadalmi beágyazottságának vizsgálatakor ugyanakkor nézőpontjaink kapcsolódnak a cselekvőhálózat-elmélethez is (BERKI M. 2017). Egyrészt a nemzeti parkok hálózatát formáló aktorok bemutatásával, másrészt az aktorként értelmezett nemzeti parkok társadalomban elfoglalt helyzetében bekövetkező változások nyomon követésével.

Mivel a hazai geográfus közösség számára ez sokáig parciális témának számított (különösen a 20. század második felében), ezért hiánypótló jelleggel a hazai, a Földrajzi Közleményekben megjelent tanulmányok diskurzuselemzése mellett főként a rendelkezésre álló angol nyelvú szakirodalom segítségével követjük nyomon a nemzeti park koncepciójának alakulását és megvalósulásának fordulópontjait a kezdetektől a 21. századig, amikor a nemzeti parkok a környezetvédelem és az idegenforgalom (ökoturizmus) révén is felértékelődnek (MichalKó, G. 2005). Jelen tanulmányunkban nem térünk ki a hazai nemzeti parkok alapításának körülményeire, nem csupán terjedelmi korlátok miatt, hanem azért is, mert írásunk célja kifejezetten a nemzeti parkok nemzetközi koncepciójának megismertetése a hazai olvasóközönséggel. A magyarországi, nemzeti parkokkal kapcsolatos gondolkodásmód változásának bemutatását egy másik tanulmányunkban közöljük majd.

\section{A nemzeti park eszméjének megjelenése}

A nemzeti park gondolatát a 19. században a Vadnyugat természeti szépsége ihlette. A lenyưgöző táj megőrzésének szükségességét az utókor számára elsőként GEORGE CATLIN fogalmazta meg (1. ábra). Az 1830-as években több évig utazott vadnyugati tájakon, 
miközben számos rajzot és festményt készített az itt élő indiánokról és az őket körülvevő természetről. Tőle származik az a gondolat, hogy az állam, a nagypolitika védje ezeket a területeket és ôrizze meg őket eredeti állapotukban, ne engedje korlátlanul érvényesülni a természetátalakító pionírok érdekeit (CATLIN, G. 1844). Catlin alkotta meg a nemzet parkja (Nation's Park) kifejezést, amit az amerikai nép identitásának kontextusában értelmezett (Frost, W.-HALL, M. 2009a). Catlin szerint ezek az érintetlen helyek különleges szépségú kincsei Amerikának, amit meg kell tartani és meg kell őrizni a jövő nemzedékeinek, továbbá meg is kell mutatni a világ többi részének (idézi NASH, R. 1970/2014 p. 101). Megőrizni (,to preserve”), megvédeni (,to protect”) és megmutatni (,to present”) - a nemzeti parkok mai hívószavai már a kezdetektől alapvető elemei a hozzájuk kapcsolódó diskurzusoknak.

A nemzeti parkok kialakításában, gyakorlati kivitelezésében JoHn MuIRnak jutott nagy szerep az Egyesült Államokban (1. ábra). Munkásságának elsődleges célja az volt, hogy a nagypolitika figyelmét felhívja a páratlan szépségú nyugati tájak védelmére a pionírok pusztításaival szemben. A nemzeti parkok atyjaként emlegetett Muir mozgalmát siker koronázta (MCConNELL, G. 1954). Így került állami védelem alá a Yosemite-völgy (ami 1890-ben lett nemzeti park), majd alakították meg 1872-ben a világ első nemzeti Parkját, a Yellowstone-t, az Amerikai Egyesült Államok Wyoming államában (HoRvÁTH G. 2019).
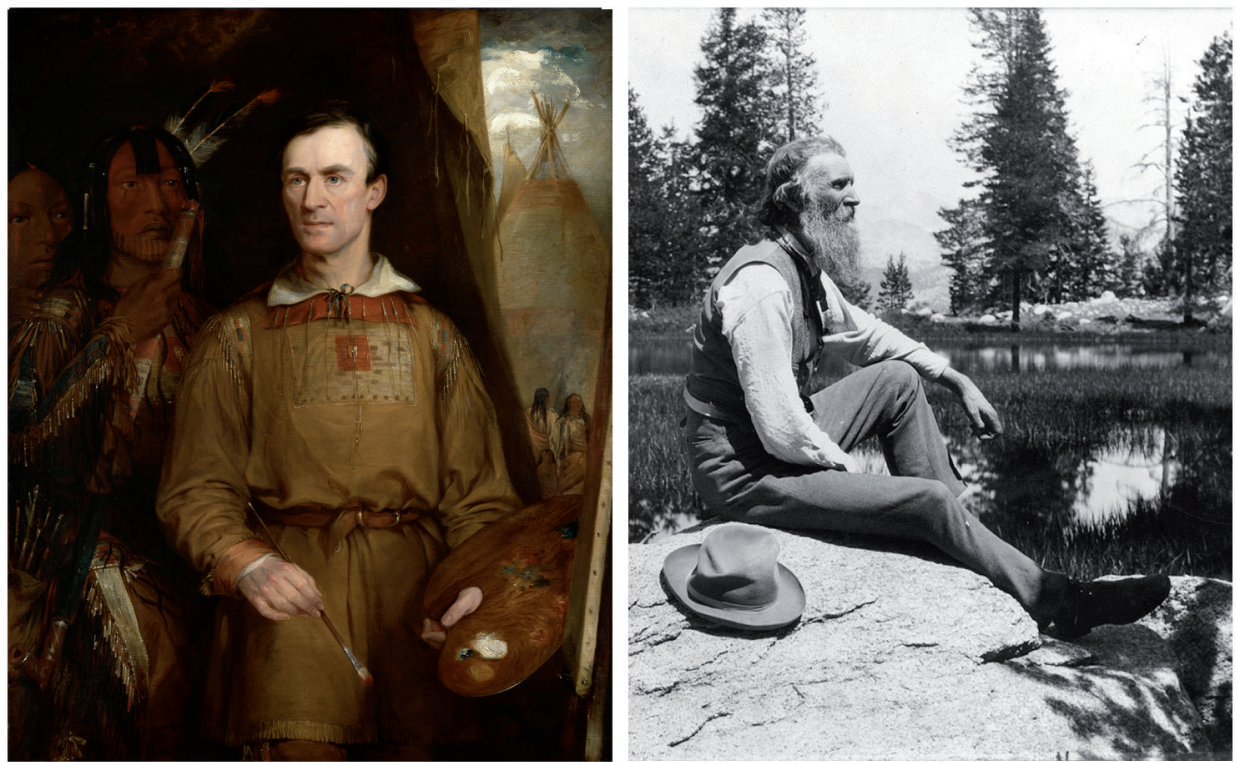

1. ábra George Catlin, a nemzeti park gondolatának első felvetője és John Muir, ,,a nemzeti parkok atyja”

Figure 1 George Catlin, the first who raised the idea of a national park, and John Muir, the ,father of national parks" Forrás/Source: https://commons.wikimedia.org/w/index.php?curid=21870636; https://commons. wikimedia.org/w/index.php?curid=40843989

Sajátos kettőssége ez az amerikai identitásnak: a kitartó munkájukra büszke pionírok hívják életre a tevékenységük által töredék területre visszaszorított természet védelmét. A nemzeti park fogalma a kezdeti, 19. századi időszakban összekapcsolódott a vadonnal (,wilderness”), azokkal a helyekkel, ahová nem ért el az emberi civilizáció a maga átalakító tevékenységeivel és annak természetre nézve káros hatásaival (CRONON, W. 1995; ThOREAU, H.D. 1854/2015). A természetet meghódítani kívánó pionírok és a természet szépségét megfogalmazó romantikus gondolkodók, múvészek tevékenysége egyaránt a mo- 
dern életmód eredményeként jelentkezett a 19. században (Frost, W.-HALL, M. 2009a). Az első nemzeti parkok kialakítása kifejezetten olyan területeken történt, ahol a pionírok természetátalakító tevékenysége és a természet szépségeit megőrizni kívánók nem keresztezték egymás érdekeit.

A nemzeti park elnevezés utalt arra a tényre, hogy az Amerikai Egyesült Államok szövetségi köztársaságában nem az adott állam fennhatósága alá tartozik a védendő terület, hanem az Egyesült Államok szövetségi kormányzata rendelkezett fölötte (FrOST, W.-HALL, M. 2009a). Az állami park elnevezés helyett ezért használták a nemzeti parkot. A szóösszetétel tehát nem a nemzeti identitás kifejezésére, hanem az állami és a szövetségi ellenőrzés megkülönböztetésére szolgált. A nemzeti park szóösszetételt RAPAICS RAYMUND magyarázta meg a hazai olvasóközönségnek a két világháború közötti időszak magyar szellemi életének egyik meghatározó folyóiratában, a Magyar Szemlében, 1931-ben: „kongresszusi határozattal alapították ,a népnek hasznára és örömére”, miként ezt főbejáratának kapuján ma is hirdetik a vésett betúk" (RAPAICS, R. 1931, p. 342).

Annak hátterében viszont, hogy az elnevezés igen gyorsan gyökeret vert az Amerikai Egyesült Államok kongresszusa által ellenőrzött természeti területeken, nemzeti törekvés is megfogalmazódott: a véres polgárháború után az egységet igyekeztek erósíteni (FrosT, W.-HALL, M. 2009a). A 18. század végén, a függetlenségi háború következtében születő új nemzet kollektív azonosságtudatának alakulásában fedezte fel azt a kulcsfontosságú mozzanatot, amikor a közösség keres valamit, ami a sajátja, ami amerikaivá teszi az új állam anyaországtól függetlenedő lakóit. Ebben a legalizálási folyamatban jelent meg a „vadon" (wilderness) mint közös érték. Az amerikai történelem rövidsége, a formálódó hagyományok, a csekély számú írott és képzómúvészeti alkotások nem vehették fel a versenyt Európával. Az új nemzetnek azonban volt valamije, ami az öreg kontinensen már szinte teljesen eltûnt: az érintetlen természet hatalmas területei. Jóllehet, az amerikai nemzeti büszkeség elsődleges forrása a vadon fokozatos meghódítása volt, de ehhez hamarosan társult a vadon érték ként, amerikai sajátosságként, tulajdonként való értelmezése is (NASH, R. 1970/2014). Az nemzeti identitásban betöltött helye révén a nemzeti park eszméje gyorsan elterjedt a köztudatban és a gyakorlati megvalósítás is megindulhatott. RAPAICS RAYMUND már idézett írásában ezt a jelenséget egyszerúen úgy fogalmazza meg, hogy az USA polgárainak vérében van a természetvédelem (RAPAICS R. 1931).

A világ első nemzeti parkjáról az 1873-ban alapított Földrajzi Közlemények hasábjain is született leírás. HuNFALVY JÁNOS egyrészt nagyszerú tudományos eredményként méltatta a Yellowstone völgyének feltárását és részletes leírását, másrészt viszont utalt a nemzeti park ká nyilvánítás pozitívnak értékelt következményeire is: a területet állami védelem alá vonták, és megindultak a munkálatok az érdeklődő, pihenni és gyógyulni vágyó nagyközönség fogadásának biztosítására is (HunFALVY J. 1874). A Yellowstone völgye valóban igazi vadonnak számított, területén az őslakos indiánok sem telepedtek le. Több kísérlet után az első hivatalos leírás egy 1870-es expedíciót követően született T. V. HAYDEN, geológus tollából (HoRvÁTH G. 2019). Az ő jelentése alapján készítette el egy magyar szerző írását a Földrajzi Közleményekben, 1878-ban (A.M.I. 1878). A jelentés arról biztosította a kongresszust, hogy a völgy területén nincs múvelésre alkalmas terület és nincsenek ipari hasznosításra alkalmas értékes ásványkincsek sem, továbbá magassága okán emberi letelepedésre sem alkalmas. További érvként szerepelt a nemzeti parkká nyilvánítás mellett, hogy nem kellett tulajdonostól megvásárolni a földet, csupán ki kellett vonni az értékesítés lehetőségének hatálya alól. A további érvelés tulajdonképpen arra a retorikára épült, hogy a termelő tevékenységre alkalmatlan területet hogyan lehet hasznosítani az emberek számára. Nem csupán az idegenforgalom, hanem a gyógyászati előnyök mellett is érveltek, így a modell tulajdonképpen a nemzeti parkot, mint szolgáltatási lehetőségek tárházát adta 
el a kongresszus felé. Ahhoz, hogy ez múködjön, az államnak szabályokkal kellett megvédeni a természeti szépségeket a gazdasági átalakító tevékenységektől, ugyanakkor a park egyes részein mégis engedélyeket adhatott olyan épületek emelésére, amelyek a nemzeti parkba érkezők ellátását szolgálták.

A nemzeti parkok kialakításának koncepciója tehát piaci érdekek mentén formálódott - olyan területek hasznosítását jelentette, amelyek a termelő tevékenységek szempontjából nem jöhettek számításba. A terület természeti értékeinek védelme olyan törekvésnek számított, ami romantikus mítoszként adta a hátteret bizonyos területek állami kisajátításához, szolgáltató ágazatok állam által történő múködtetéséhez. Az így ellenőrzött vadon azonban már nem lehet az, ami előtte volt: szabadidős tevékenységek festői szépségú hátterét adta. Az 1870-es évektől egyre dinamikusabban kapacitálták a Vadnyugat természeti szépségeinek fogyasztására az átlag amerikai polgárokat (WYCKOFF, W.-DiLSAVER, L. M. 1997). Az első transzkontinentális vasútvonal 1869-es befejezését követôen a vasúti társaságok is érdekeltek voltak a nemzeti parkok létrehozásában. Bevételeik növelése érdekében hathatós segítséget nyújtottak a népszerúsítésükben is (FrOST, W.-HALL, M. 2009a; WYCKOFF, W.-DiLSAVER, L. M. 1997).

A korabeli retorika a természet védelmének pozitív oldalait hangsúlyozta (COMSTOCK, T. B. 1874). Ezt az interpretációt is megismerhetjük a Földrajzi Közleményekből: „Magánosok birtokot nem szerezhetnek e helyütt, gyárak nem emelkednek itt s a természet gyönyörü vidéke üzleti czélokra nem használható fel." (GYÖRGY A. 1881). A múködtetésben már a kezdetektôl dominált a piaci jelleg: a látogatók számának, ezáltal a bevétel mennyiségének növelését célozták meg (2.ábra). Érdekes adalékot olvashatunk erről CHOLNOKY JENőtől 1912-ben a Földrajzi Közlemények hasábjain: „Nagy omnibusz szerü régi módi kocsikon utazza be az ember a park látnivalóit, hotelröl hotelre, amelyek ugyan festóien szépek, de a kiszolgálás bennük nagyon silány, igazi monopóliumjellegü. A rossz kocsiútak folyton silány fenyvesek közt vezetnek, ahol édes kevés a látnivaló.... Azt hiszem, hogy azért nem vezetik itt be az autókat, mert akkor a turisták legnagyobb része egy-két nap alatt végezne az egésszel s ez a hotelekre nézve érzékeny veszteséget jelentene." (CHOLNOKY J. 1912)

\section{A nemzeti parkok elterjedése}

Az állami érdekek mentén felkarolt, természetes állapotukban megőrizni kívánt, emberi átalakító tevékenységektől mentes területek lehatárolása és látogathatóvá tétele kezdődött meg az Amerikai Egyesült Államokban és ennek mintájára szerte a világban. A nemzeti parkok alakítását támogató politikai szándék nyomán hamar kiépült a nemzeti parkok hálózata az Egyesült Államok területén (WAUGH, F. A. 1918). A hálózat terjedését segítette az a tény, hogy az alapítások időszaka egybeesett az állam nagy térképezô és feltáró munkájával, ami kifejezetten a terület megismerésének céljával számtalan tudományos kutatócsoportot és expedíciót támogatott.

Az alapítások hátterében gyakran húzódnak helyi kezdeményezések, amelyek szerencsésen ötvöződtek az állam érdekeivel (Rövid közlemények 1900). A nemzeti parkok létezését törvényileg is szabályozták, múködésük meghatározója lett az 1916-os „Organic Act” (Anderson, M.K.-BArbour, M.G. 2003). A 20. század első felében tehát nemzeti szinten már megjelent az igény az egyes nemzeti parkok múködésének összehangolására (erre hozták létre a mai napig múködő National Park Service-t) (SCHNEIDER-HeCTOR, D. 2014; WAUGH, F. A. 1918), ami a második világháborút követően öltött nemzetközi méreteket. A második világháború idejére az Egyesült Államok területén létesített nemzeti parkok száma már húsz felett volt (FrOST, W.-HALL, M. 2009a). 


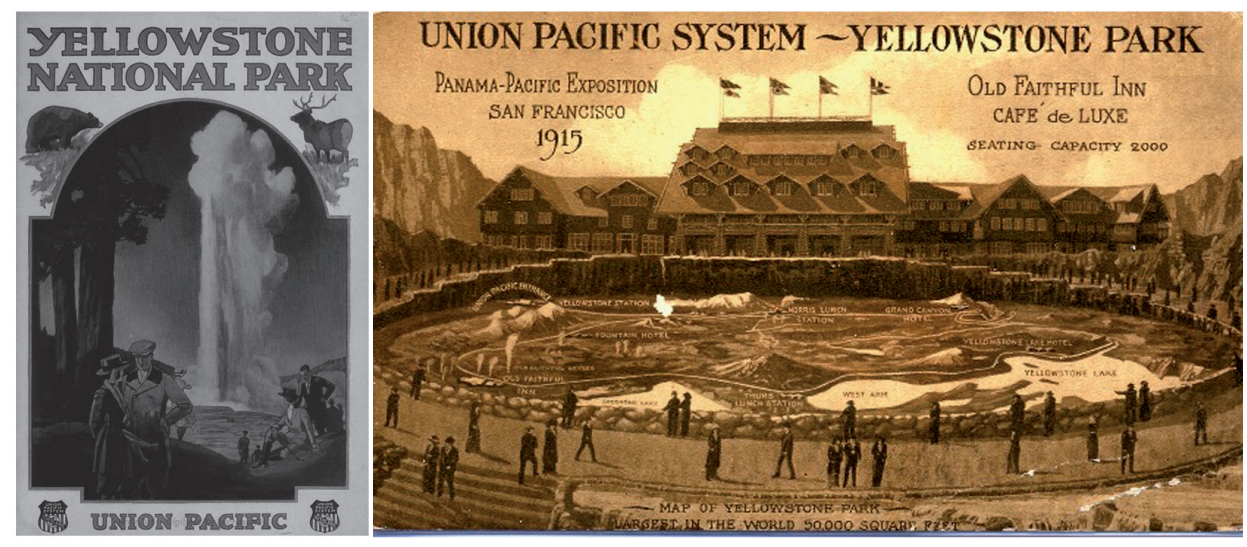

2. ábra Plakát és képeslap a Yellowstone Nemzeti Parkról

Figure 2 Poster and a postcard from Yellowstone National Park

Forrás/Source: https://en.wikipedia.org/wiki/Yellowstone_National_Park\#/media/File:Union_Pacific_Yellowstone_ National_Park_Brochure_(1921).JPG; http://geyserbob.org/attachments/Image/hot-ofi-ppie_uprrpc.jpg

A nemzeti park koncepciójának gyakorlati megvalósításában igen fontos szempont volt az állam oldaláról, hogy bizonyos földterületek közvetlen állami ellenőrzés alá kerülhettek. Ez nagyban elősegítette a nemzeti parkok gyors terjedését az Egyesült Államok területén kívül is. Különösen azokon a gyarmati területeken, ahol az irányító hatalom minél jobban biztosítani szerette volna pozícióit (GAYNOR, A. 2017; MUKHERJEE, A. 2009; CARRUTHERS, J. 1989). Az állami érdekek egy másik eleme is ösztönözte a nemzeti parkok koncepciójának felfutását, nemzetközivé válását. Az érintetlen természet megórzése együtt járt az életvitelszerű emberi jelenlét megszüntetésének elvével, így az érintett területen élő őslakosok elüzésével (ANDERSON, M.K.-BARBOUR, M.G. 2003). A természet védelmét szolgáló Yellowstone modell egyszerre vált a termelésre alkalmatlan területek állami hasznosításának és az őslakosok elleni politikai támadásoknak hathatós eszközévé. Gyors terjedése összefüggésben állt a gyarmatosítók érdekeivel: hamarosan másolták a brit domíniumok területén, néhány évtizeddel később pedig afrikai és ázsiai gyarmati birtokokon is. A nemzeti parkok létrehozása, a területek elzárása, a lakosság áttelepítése sok esetben heves ellenállást váltott ki a helyiekből (MuKHERJEE, A. 2009). Az őslakosok és a nemzetei parkok kapcsolata azonban a turizmus felfutásával bonyolultabbá vált. Az érkező turisták nem csak a vadon szépségeire, hanem a helyiek kultúrájára is kíváncsiak voltak. Ahogyan a vadnyugati tájakon az indiánok, úgy a gyarmati területeken a törzsi közösségek jelentették a különleges egzotikumot, így a nemzeti parkok népszerúsítésében hamarosan fontos szerephez jutottak (WyckofF, W.-DiLSAVER, L. M. 1997). A helyi lakosság kultúrájának és hagyományainak védelme azonban kezdetben nem tartozott a nemzeti parkok feladatai közé.

A gyarmati területeken a külső hatalom térfoglalásaként értelmezhetjük a nemzeti parkok alakításának kezdeti lépéseit. Olyan területeket jelentettek, amiket a hatalom kivont a mindennapi életből, elzárt a hagyományos életvitelt folytató helyiek elől (WEST, P. et al. 2006). A nemzeti parkok várták a látogatókat, azonban ezek a látogatók sosem az adott országban élők, hanem a gazdag országok módos utazói voltak, akik számára biztosították a helyi természeti szépségek zavartalan élvezetét. A gyarmati területeken, különösen a domíniumokon sokszor meghatározónak bizonyult az a nézőpont, ami kifejezetten a rekreációs tevékenységek lehetősége okán támogatta a nemzeti parkok létrehozását. A megnyugtató, egészséges és látogatható környezet, ahová a kirándulni, vagy éppen gyógyulni vágyókat várták, nem a vadon megőrzése, hanem az ember számára élvezhetővé 
alakított természet okán volt vonzó, ezért a védett területek park jellegét erősítette (HALL, C.M.-Frost, W. 2009). Ennek szép példája Ausztrália első nemzeti parkja.

A nemzeti parkok terjedésével tehát ugyanazon elnevezéssel valójában a helyi politikától, közösségektől és lehetőségektől függő különböző változatok kezdtek formálódni (DuNLAP, T. R. 1999). Európa a maga területén másként értelmezte/értelmezhette a nemzeti park eszméjét, ahol kevésbé volt meg a nemzeti parkok alapításának lehetősége, a nagyobb népsűrûség, a kisebb területek és a természetátalakító folyamatok hosszú évszázadokra visszanyúló hatásai okán. A ritkán lakott északi területeken, illetve a magashegységekben, Svédországban, Svájcban és Spanyolországban alapítottak elsôként nemzeti parkot (FrosT, W.-HALL. M. 2009b; Rövid Közlemények p. 394) (3. ábra).

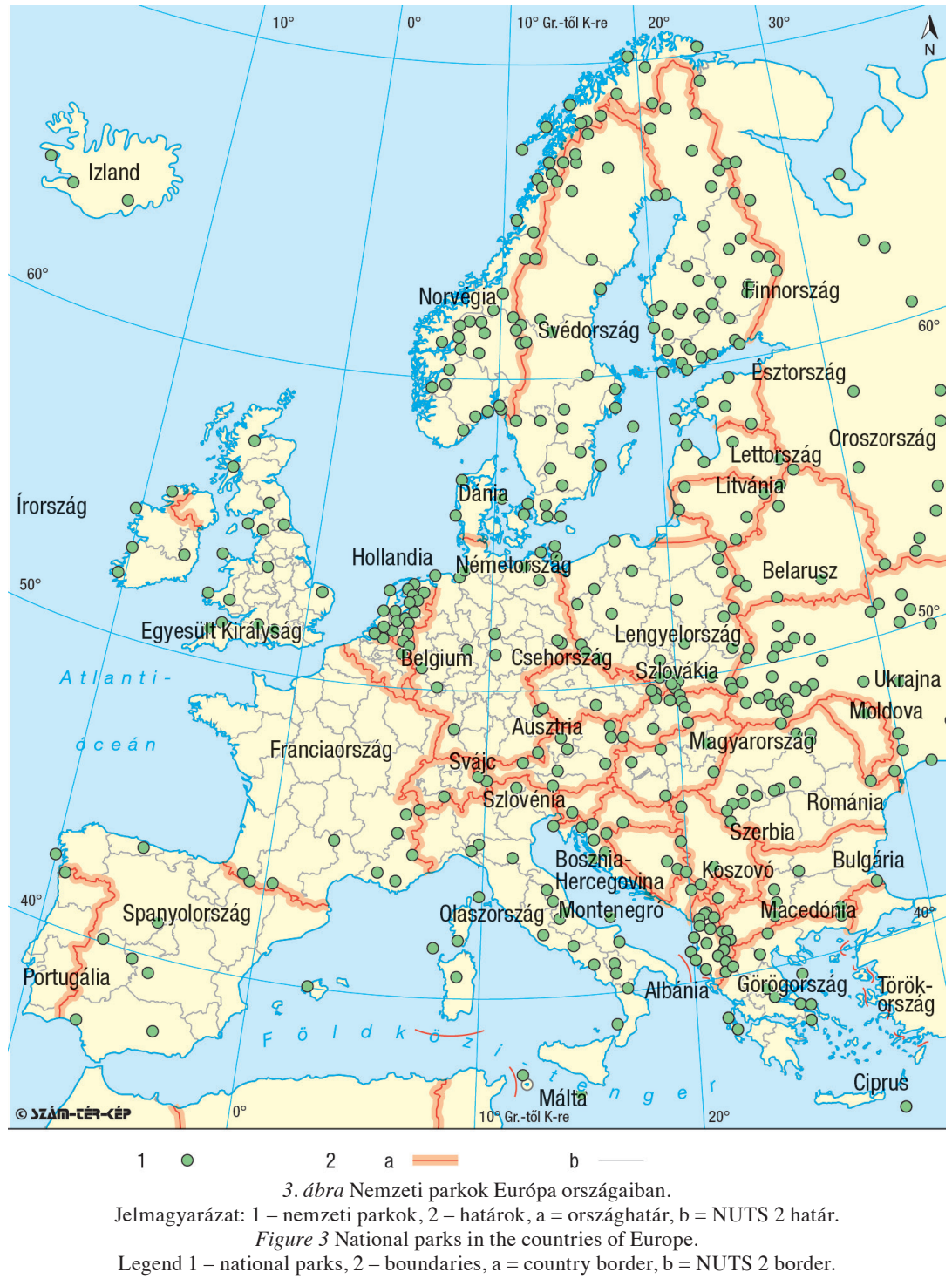


A hatalmas kiterjedésű, közel érintetlen természeti tájak az öreg kontinens nagy részén hiányoznak, sokkal inkább az iparosodó nagyvárosokban élők számára megnyitott közparkok példája nyomán bontakozott ki a vidéki tájak látogathatóvá tételének igénye (FROST, W.-HALl, M. 2009a). A védelem érdekében sürgetett nemzetközi összefogás és ennek szervezése azonban kifejezetten Európához köthető. Ez összefüggésben állt azzal, hogy a nagy gyarmatbirodalmak európai anyaországai (Nagy-Britannia, Franciaország, Belgium) nem saját területükön, hanem a fentebb már kifejtett okok miatt gyarmataikon szorgalmazták a nemzeti parkok alapítását (HALL, C.M.-Frost, W. 2009).

Bizonyos európai országok esetében sajátos jelentőséget kapott a nemzeti jelleg a természet védelmében lehatárolt nemzeti parkok esetében, ami különösen az első világháborút követően, a határok jelentős módosulásával válik értelmezhetővé (FROST, W.Hall. M. 2009a). A nemzeti parkot alapító államok (pl. Olaszország, Jugoszlávia, Görögország, Lengyelország, Izland, Írország, Románia) zöme korábban európai nagyhatalmak befolyása alatt állt, saját területük, saját értékeik védelmét látták a nemzeti park eszméjében (Frost, W.-HALL. M. 2009a): az egész nemzet közös tulajdonává tenni a különleges szépségú területeket, kifejezni a nemzet fennhatóságát a természeti szépségek felett (is). A két világháború között a nemzeti parkok alakítása így Európa keleti felén is gyakorlattá vált (3. ábra). Kivételt jelent ez alól Magyarország, amely ebben a kontextusban éppen a másik oldalt képviselte. A széteső Osztrák-Magyar Monarchia részeként elveszítette területei jelentôs részét, így a hazai tudomány által felkarolt kezdeményezéseknek (melyeket egy másik tanulmányunkban mutatunk be részletesebben) nem maradt társadalmi támogatottsága.

\section{A nemzeti parkok nemzetközi hálózata}

A nemzeti park alapkoncepcióját igazi amerikai termékként (brand) azonosította ugyan RODERICK NASH, azonban már a két világháború közötti időszakban, de különösen a második világháború után az amerikai jelleg egyre inkább háttérbe szorult. Más amerikainak tekintett gazdasági produktumokhoz hasonlóan (mint a Coca-Cola, vagy a McDonald's) a „nemzeti park” koncepciója is szerte elterjedt a világban. Egy az Egyesült Államokból induló, nemzeti identitás tekintetében eredetileg amerikai modell nemzetközivé válásáról („,nemzetköziesedés”, internationalization) lehet beszélni (Frost, W.-HALL, M. 2009a). Noha az egyes országok másolták a Yellowstone modellt (4. ábra), a szervezésben és a múködtetésben teljes önállóságuk volt.

Már a két világháború között megfogalmazódott Európában annak az igénye, hogy a nemzeti parkok révén megvalósuló természetvédelem integrálódjon egy nemzetközi hálózatba, kapjon nemzetközi hátteret (BISHOP, K. et al. 2004). A második világháborút követően az ENSZ megalakulásával tulajdonképpen létrejött az az ernyőszervezet, ami felvállalhatta a természeti értékek nemzetközi védelmét. Az UNESCO részeként, 1948ban alapított Természetvédelmi Világszövetség (IUCN - International Union for Conservation of Nature) 1958-ban hozta létre a védett területekkel foglalkozó, tervezési és tanácsadási szolgáltatásokat nyújtó bizottságot (WCPA - World Commission on Protected Areas). Az ENSZ 1962-ben tette közzé először a nemzeti parkok listáját, az IUCN pedig hivatalosan meghatározta a védett területek kategóriáit, közöttük a nemzeti parkokat. A védett területek hálózata az 1970-es évektől gyorsabb ütemben bővült, a növekedés üteme az 1980-as és 1990-es években érte el a csúcsot (WEST, P. et al. 2006) Ezen belül a nemzeti parkok számának növekedése viszont egy évtizedes késéssel követte ezt a trendet (5. ábra). Viszont nem alakult ki egy olyan nemzetközi kritériumrendszer és akkre- 
ditációs eljárás, ami valóban egységesítené a nemzeti parkokat, ezért nagyon heterogén képet mutatnak szerte a világban (HALL, C.M.-Frost, W. 2009).

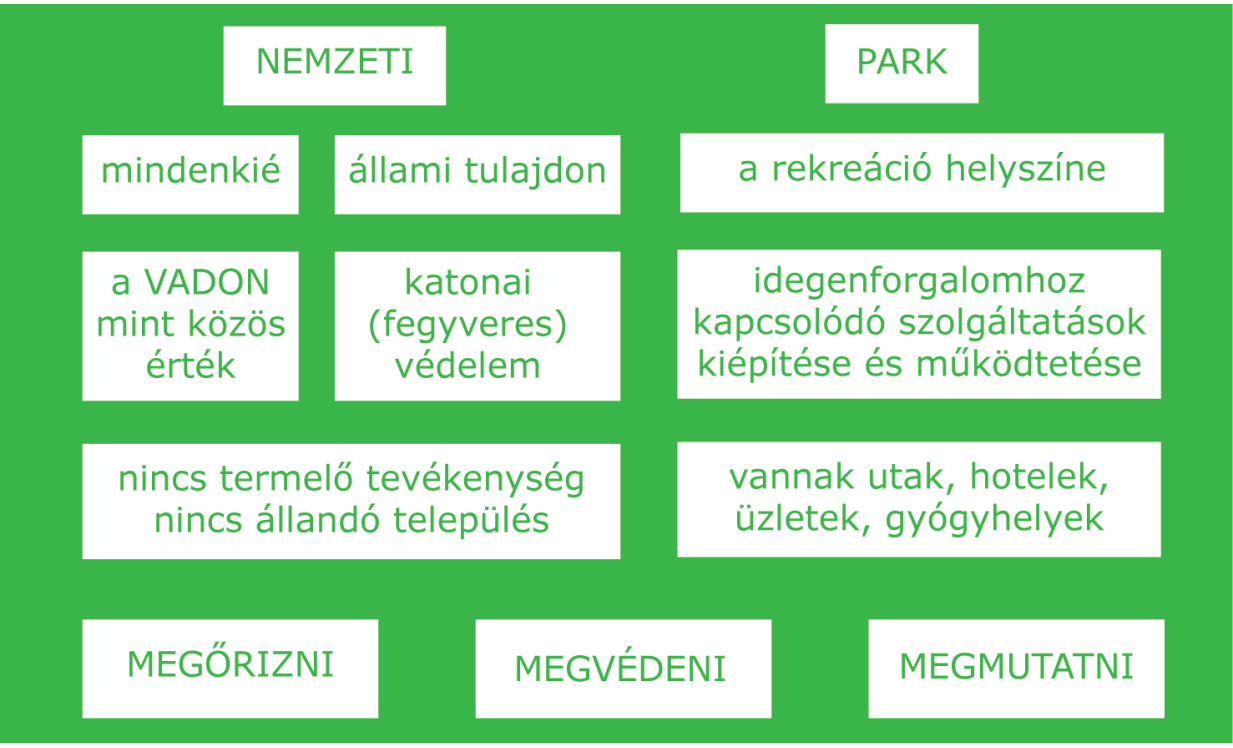

4. ábra A Yellowstone modell vázlata

Figure 4 The elements of the Yellowstone model

Forrás/Source: saját szerkesztés/authors' own

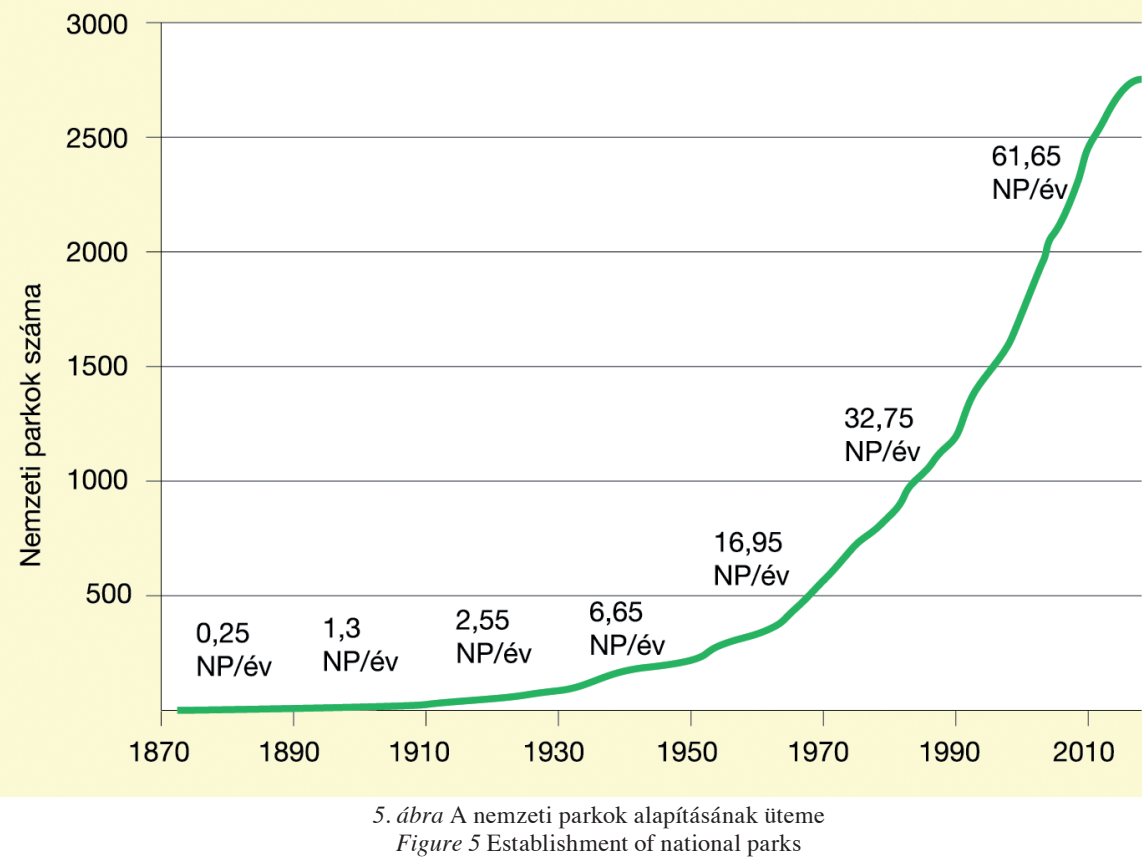


A nemzeti parkok kialakításának gyakorlati lépései az Egyesült Államokban megalkotott, majd a 20. században nemzetközivé vált modell alapján történtek, az eredeti hármas elv lehetőségek szerinti érvényesítésével. Természeti értékek megőrzése a terület állami (jogi) védelme alatt, miközben kiemelt cél ,,a terület bemutatásra, látogatásra, ismeretterjesztésre való alkalmassá tétele" is (HoRvÁTH I. et.al. 1972). A nemzetállamok világszintú kialakításával együtt vált szimbólummá a nemzeti parkok alapítása, a polgári létforma rekreációs tevékenységeinek színtere, a nemzeti büszkeség reprezentációja (HALL, C.M.-Frost, W. 2009). A szabadidő eltöltése mellett azonban hamarosan egyre fontosabbá vált védelmi és megőrzési funkciók hangoztatása is.

A 20. század második felében a tudományos gondolkodásmódban is bekövetkező módosulások a nemzetközi hálózat elveit is változtatták, miközben a nemzetközi jelleg érvényesülésével az eredeti koncepció is átalakult. A természetvédelem ügye összefonódott azokkal az ökológiai mozgalmakkal, amelyek már az 1950-es években megjelentek a modernizációban leginkább elöljáró nyugati országokban, így az Egyesült Államokban is (BEATTY, R. O. 1952). Az ipari társadalmak által okozott szennyezések és káros hatások megfogalmazása, a fenntarthatóság kérdése különösen az 1970-esévektôl vált társadalmi mozgalmak tevékenységeinek alapjává, hívta életre a hálózatosodást világszinten e kérdéskörben (CRONON, W. 1995; WEST, P. et al. 2006).

A tájak védelmének kérdése összetettebbé vált, a természeti értékek védelme mellett a társadalom alkotásai és tevékenységei is jelentőséget kaptak (PESsIS, A-M.-Guidón, N. 2007). Ugyanakkor a gondolkodásmódban bekövetkező változások egyik igen fontos ismérve a tudományos eredmények felértékelődése a társadalom életében (LATOUR, B. 1993). A sérülékeny környezet vizsgálatában egyre nagyobb publicitást kapott a nemzeti parkokban folyó kutatások jelentősége, ami ráirányította a figyelmet e területek tudományos jelentőségére is.

A nemzeti parkok értelmezésében az Egyesült Államokban is történt módosulás a 20. század második felében. Az 1964-es „Wilderness Act” a vadon és annak megőrzése mellett hangsúlyozta a természeti és történelmi objektumok védelmét, annak fontosságát, hogy jelen és jövő generációi egyaránt örömüket lelhessék a védett természeti kincsekben (Anderson, M.K.-BArbour, M.G. 2003). Tehát új elemként megjelent és egyre nagyobb szerepet kapott a 20. század során a történelmi örökség védelme is (MILLER, P. P. 1987). Ugyanakkor ebben a szabályozásban már az ökológiai megközelítés is fontosabbá vált, figyelembe vette az őslakosok által átalakított kultúrtájak sajátosságait is (ANDERSON, M.K.-BARBOUR, M.G. 2003).

A nemzeti parkok esetében már a megalakulásuktól ambivalens volt a kapcsolat a természeti értékek védelme és a velük kontaktust kereső társadalom között (WEST, P. et al. 2006). A nemzeti park egyszerre jelent elzárást a társadalomtól, valamint szigorú szabályok szerinti való nyitást az emberek felé. A természetvédelem és az idegenforgalom érdekei sokszor keresztezték egymást, folyamatosan változott, hogy melyik vált éppen dominánsabbá a másikhoz képest (PuHAKKA, R. 2008). Konfliktusos helyzetté ez a kettősség akkor vált igazán, amikor a turizmus tömeges jelenséggé vált a 20. század második felében, helyi és globális szinten egyaránt. A nemzeti parkokba tömegesen látogató ember számos módon lenyomatot hagy a természetet megórizni és megvédeni kívánó terület életében, így végső soron a természet védelmével ellentétes módon hat (SABO, H.M. 2012).

Míg az USA esetében az amerikai nép saját értékének tekinti a nemzeti parkokat, addig más országokban az átvett modell számos esetben nem járt együtt ezzel a mentális megközelítéssel. A társadalomtól részben elzárt területen felállított szabályokat nem mindenhol tekintették sajátjuknak. Így válhatott például a fehérek kultúrájának szimbólumává a nemzeti park a Dél-Afrikai Köztársaságban (CARRUTHERS, J. 1989). Bizonyos nemzeti 
parkok megszűntek létezni a gyarmati hatalom alól függetlenedő országokban azért, mert a korábbi elnyomó rendszer jelképét látták benne (HALL, C.M.-Frost, W. 2009).

A nemzeti parkok létrehozásának alapja a Yellowstone modell, aminek értelmében emberi településektől mentesek a védendő területek. Megalakításuk gyakran járt a helyi lakosok szervezett áttelepítésével, a területre való belépés korlátozásával, vagy erőszakos költöztetéssel. Különösen a harmadik világ országaiban vált gyakran a diktatórikus állami vezetés politikai eszközévé ez az eljárás (CARRUTHERS, J. 1989). Az IUCN által létrehozott kategória-rendszerbe illesztik be a nemzeti kormányzatok az állam által védett területeiket, ami egyben az elkülönítés eszközeként funkcionál az emberek és a körülöttük lévő világ között. Az ökológiai szemlélet térnyerésével azonban a helyi lakosság hagyományos életformájának megítélése is jelentôsen módosult, a 20. század második felében kultúrájuk védelme már kifejezetten a nemzeti park által védett értékek sorában foglalt helyet (HILL, M. A.-Press, A. J. 1993; Fine, K. 1988). A szemléletmódbeli változások elősegítették a nemzeti parkok számában a 20. század második felében bekövetkező ugrásszerú növekedést: az újonnan kialakított védett területek magukba foglalhattak emberek által lakott és használt részeket is (GAYNOR, A. 2017). A nemzeti park megalkotása így viszont feszültséget indukálhat a helyi lakosság és az állam között, a kirekesztés eszközeként múködhet, vagy egy ilyen eszközt láthatnak benne a nemzeti parkok közelében élők (MUKHERJEE, A. 2009; Wallsten, P. 2003; Aagesen, D. 2000).

A nemzeti parkok alapításának mennyiségi felfutásában az állami (hatalmi) érdekek érvényesülése mellett gazdasági szempontok is igen jelentős szerepet játszottak. Mivel idegenforgalmi szempontból vonzó desztinációnak számítanak, ezért számos országban olyan területet is nemzeti parkká nyilvánítottak, ahol valójában nem volt kiemelkedô védett természeti érték (WEST, P. et al. 2006). Az idegenforgalom felfuttatásában ily módon találkoznak a helyi és állami érdekek, azonban ez nem feltétlenül felel meg a vadon védelmeként megfogalmazott eredeti céloknak. A turizmus túlzott eróltetése éppen az ellentétes hatást, a védett értékek lassú (vagy bizonyos esetekben kifejezetten gyors) pusztulását eredményezheti.

Sajátos helyzetben voltak a nemzeti parkok alapítása szempontjából a keleti blokk országai, az egykori Szovjetunió és az érdekszférájához tartozó szocialista szatellit államok. A Szovjetunió ideológiai megfontolásból minden nemzetközi mozgalmat támogatott, így a természetvédelem hálózatának kiépítését is elfogadta. Szintén ideológiai okokból azonban nem vette át a nyugati imperialista terminust (Frost, W.-HALL. M. 2009b). A Yellowstone Nemzeti Park létrehozásának centenáriuma nyújtott megfelelő alkalmat az alapításokhoz, azonban az orosz vezetés a nemzeti park helyett a néppark elnevezést kívánta alkalmazni a keleti blokkban nem szalonképes nemzeti jelző kikerülésével. A nemzeti parkot alapítani kívánó tagállamok azonban hathatós érvet találtak Lenin egyik írásában, aki az amerikai mintájú nemzeti parkok alapítására buzdított (SCHWARTZ, K. Z. S. 2006). Ezzel a fordulattal megtörtént a nemzeti park elnevezés legitimációja, így a Szovjetunión belül a balti államokban (Észtország 1971, Lettország 1973, Litvánia 1974) és Grúziában (1973) jöttek létre az első nemzeti parkok (6. ábra, 1. táblázat). Ez adott lökést a Kelet-Közép-Európai államokban történő alapításoknak is (ami pl. életre hívta hazánk első nemzeti parkját is).

Ezen országok történelmében kiemelkedő jelentőséggel bír a rurális társadalom és ennek kapcsolata a földdel, amit a 20. század eseményei, különösen a pártállami diktatúra időszaka alapjaiban forgattak fel. Ilyen történelmi szituációban nem feltétlenül alakult ki az emberekben a pozitív attitúd az állam által ellenőrzött nemzeti parkok felé, és minden természetvédelem érdekében hozott szabályozás a helyi lakosság körében ellenérzést válthat ki, mivel a korlátozó hatalom újraéledéseként élhetik meg ezeket az intézkedéseket (SCHWARTZ, K. Z. S. 2006). 


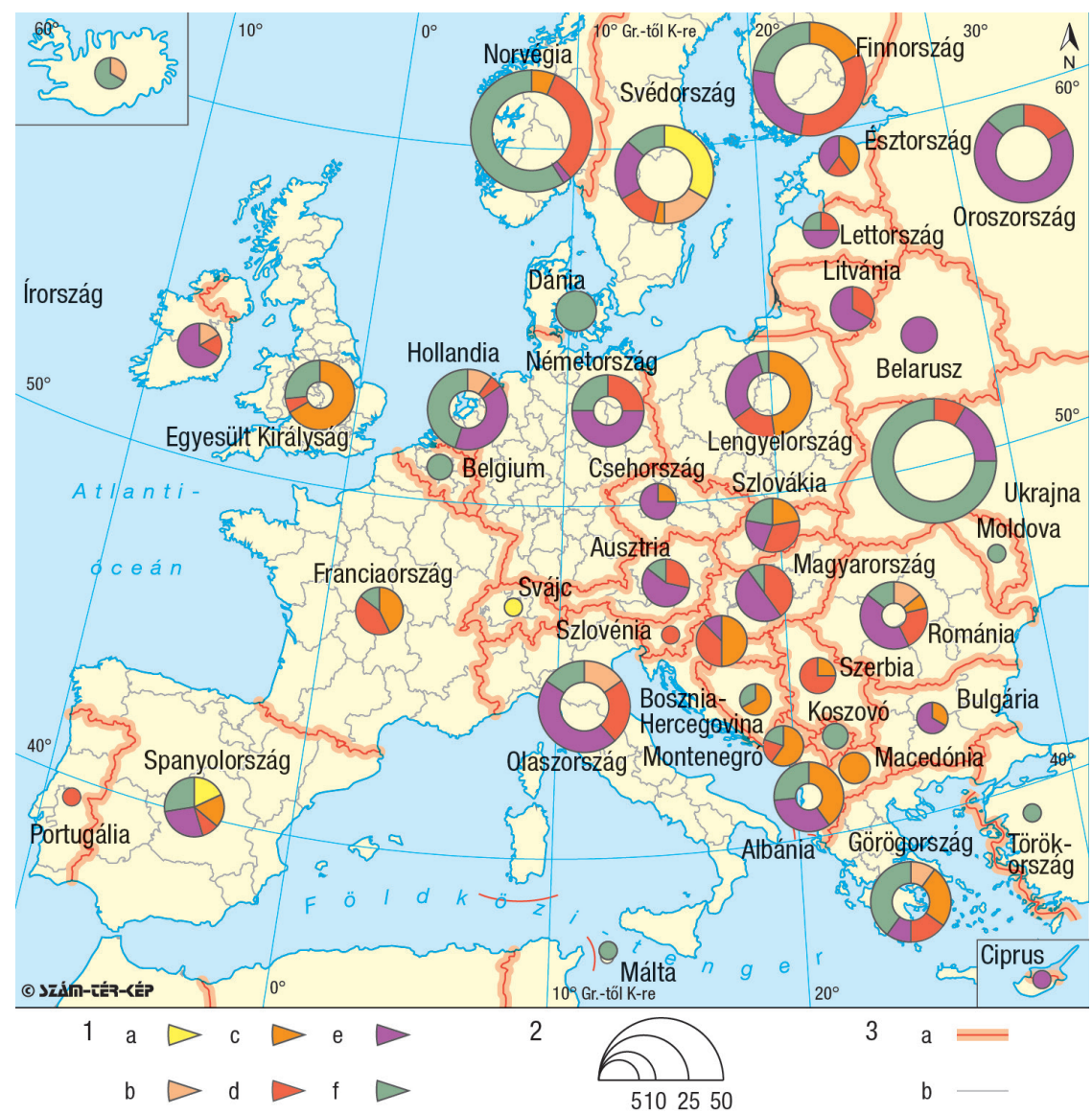

6. ábra A nemzeti parkok száma Európában, alapítási idejük szerint. Jelmagyarázat: 1 - nemzeti parkok alapítási ideje, a = 20. század eleje (1900-19018), b = a két világháború között (1919-1945), c = a hidegháború első évtizedei (1946-1969), d = az enyhülés időszaka (1970-1989), e = a rendszerváltás után (1990-2000), f = 21. század (2001-2019); 2 - nemzeti parkok száma; 3 - határok, a = országhatár, $\mathrm{b}=$ NUTS 2 határ.

Figure 6 The number of national parks in Europe by the year of foundation. Legend: 1 -the year of foundation, $\mathrm{a}=$ the beginning of the $20^{\text {th }}$ century (1900-19018), $\mathrm{b}=$ between the two world wars $(1919-1945)$, $\mathrm{c}=$ the first decades of the Cold War (1946-1969), d = the period of Détente (1970-1989), e = after the change of regime (1990-2000), $\mathrm{f}=$ the $21^{\text {st }}$ century (2001-2019), 2 - the number of national parks, 3 - boundaries, a = country border, $\mathrm{b}=$ NUTS 2 border. Forrás/Source: saját szerkesztés/authors‘ own

\section{1. táblázat - Table 1}

A nemzeti parkok száma Európában, alapítási évük szerint Number of national parks in Europe by the year of establishment

\begin{tabular}{lc}
\hline Történelmi idószak & Nemzeti parkok száma \\
\hline 20. század eleje (1900-19018) & 14 \\
a két világháború között (1919-1945) & 17 \\
a hidegháború első évtizedei (1946-1969) & 68 \\
az enyhülés időszaka (1970-1989) & 91 \\
a rendszerváltás után (1990-2000) & 131 \\
21. században (2001-2019) & 141 \\
\hline
\end{tabular}




\section{1. század: nemzeti parkok a (virtuális) világban}

A nemzeti parkok a globalizálódó világ társadalmaiban változó jelentéstartalommal bírnak. Olyan eszközökké váltak, amelyek segítségével az emberek láthatják, megérthetik, tapasztalhatják és használhatják a világ azon részeit, amit természetnek, vagy környezetnek neveznek (WEST, P. et al. 2006). A hozzájuk kapcsolódó kontextusok jelentős módosulásokon estek át, szerepük a társadalomban diverzifikálódott. A természet-alapú ökoturizmus jelentőségének növekedése, mennyiségi felfutása felértékeli a nemzeti parkok létét, miközben a helyi lakosság bevételi forrásaként is jelentős szerepet tölthetnek be a társadalom életében (EAGLES, P.F.J. 2002; PuHAKKA, R. 2008; WiLKinson, P. F. 2003). Felértékelődik az aktív pihenéshez szükséges szolgáltatások léte, valamint az ismeretterjesztésben, oktatásban betöltött szerepe is fontosabbá vált (TURNER, R. W. 2000).

A nemzeti parkok virtuális jelenléte már közel olyan fontosságú, mint konkrét megjelenésük a fizikai térben. Ez a saját internetes oldalak mellett a közösségi médiákat is jelenti. A valóság virtuális térben való interpretációját számos eszközzel igyekeznek elérni, aminek hatására tulajdonképpen minden látványosság elérhető megfelelő kommunikációs eszköz és internetes kapcsolat segítségével a világ minden tájáról. Ez ugyan szélesebb közönséget jelent, azonban valójában nem annyival, mint amennyit a lehetőség sugall. A virtuális látogatók zöme azokból kerül ki, akik a valóságban is ellátogatnak az adott nemzeti parkba (MiLLER, Z. D. 2017).

Az internet világa egyben lehetôséget nyújt a nemzeti parkok nemzetközi hálózatának hatékonyabb szervezéséhez is. Az IUCN honlapja (www.iucn.org) nem csupán információk tárházát nyújtja a szervezet tevékenységeiről, hanem egyben adatforrásként is szolgál a nemzetközi hálózathoz tartozó különféle védett területekról. Területi adatbázisában térképi alapon jelenik meg a Föld összes védett területe és az egyes elemekhez elérhető statisztikai információk (WDPA - World Database on Protected Areas, Protected Planet website; https://protectedplanet.net/). Az információs technológia alkalmazásával még inkább felértékelődik e területek tudományos jelentősége, hálózati jellegú adatgyújtéssel pedig lehetőség nyílik összehasonlító kutatások, valamint globális összefüggések kimutatására is.

\section{Összefoglalás}

Az átalakuló hazai turizmus, valamint a globalizálódó világ klímadiskurzusának hangsúlyossá válása révén a közvélemény figyelme hazánkban is a védett területek - közülük is különösen a nemzeti parkok felé fordult (GÁlosi KovÁcs B.-HORVÁTH G. 2018; HoRVÁtH G. 2019; Michalkó G. 2005; Szalai K.-SzIláGYi Zs. 2007), azonban a nemzeti parkok társadalmi megítélésének és hatásainak vizsgálata egyelőre várat magára. Kutatócsoportunk ezt a hiátust igyekszik kitölteni a közös természet- és társadalomföldrajzi vizsgálatokkal, amelyek elméleti megalapozásaként tárta fel a nemzeti park koncepciója mögött rejlő diskurzusok változásait térben és időben.

Az 1970-es évektől megjelenő nemzeti parkjaink részét képezik annak a hálózatnak, amely az ENSZ égisze alatt formálódik a 20. század második felétől. A természetvédelem kérdésének megjelenése, a nihilista gondolkodásmód változása a keleti blokk országaiban, továbbá a fenntartható fejlődés diskurzusának terjedése a világ országaiban rohamosan növelte a világ védett területeit a 20. század végére. Ugyanakkor hangsúlyoznunk kell, hogy a globális méreteket öltő hálózat alapvető koncepciója, a különleges természeti szépségekkel rendelkező tájak megôrzése, védelme és bemutatása sokkal régebbi keletû. 
Összefüggésben áll a felvilágosodás és az ipari forradalom után kibontakozó, mentalitásban és életformában is megmutatkozó változásokkal, amelyek a modernitás fogalmához kapcsolódnak. Természet és társadalom markáns, térben is megjelenő elkülönítése hívta életre az érintetlen természet (vadon, wilderness) értékként való interpretációját, és teremtette meg a gazdasági termelésbe közvetlenül nem bevonható tájak sajátos piaci hasznosítását.

A nemzeti parkok kialakításának gondolata és gyakorlati megvalósítása a modernizáció nyomán átalakuló közösségek közül elsőként ott jöhetett létre, ahol az érintetlen természet hatalmas területeken volt jelen a bontakozó kapitalizmus időszakában is, ezért a formálódó nemzet identitásának szerves részévé válhatott. Az Amerikai Egyesült Államok első nemzeti parkja vált a 19. század végétől folyamatosan bővülő védett területek megszervezésének és múködtetésének követendő mintájává. A Yellowstone modell meghódította a világot, de rohamos terjedésének okai mögött térben és időben változó hatalmi és társadalmi érdekek körvonalazódtak.

A közvetlen állami kontroll alatt tartott természeti szépségek, a társadalom mindennapjaitól elzárt tájak azonban nem feltétlenül váltak a nemzetállami keretek között élő közösségek büszkeségének kifejezőivé. Míg Európa nyugati felén a vadon hiánya és a kultúrtájak szinte kizárólagos jelenléte szabott határt sokáig a nemzeti parkok alapításának, addig a keleti blokk országaiban és az ún. harmadik világban a modell gyakorlati kivitelezése ugyan megtörtént, de a társadalom gondolkodásmódjában már kevesebb sikerrel adaptálódott, mint az Amerikai Egyesült Államokban.

Az eredeti elvek maradéktalan megvalósítását nehezíti a globalizálódó világban a turizmus tömegessé válása, amely gyakran idéz elő konfliktusokat a megőrzés és megtartás, valamint a megmutatás elve között. A népességszám növekedésével és a gazdasági kényszer erősödésével pedig a helyi lakosság érdekei kerülnek ellentétbe a természet védelme okán bevezetett korlátozásokkal. Ugyanakkor nemzeti parkok ismeretszerzésben, oktatásban és kutatásban és különböző szabadidős tevékenységekben betöltött szerepe világszinten jelentôsebbé vált az elmúlt évtizedek ökológiai gondolkodásmódjának terjedésével.

\title{
Köszönetnyilvánítás
}

A tanulmány az NKFIH 124497. számú projekt támogatásával készült.

\author{
KŐSZEGI MARGIT \\ ELTE TTK FFI Etnikai és Vallásföldrajzi Múhely, Budapest \\ koszegimargo@gmail.com \\ BOTTLIK ZSOLT \\ ELTE TTK FFI Etnikai és Vallásföldrajzi Múhely, Budapest \\ agria@gmx.net
}

TELBISZ TAMÁS

ELTE TTK FFI Természetföldrajzi Tanszék, Budapest

telbisztom@caesar.elte.hu

MARI LÁSZLÓ

ELTE TTK FFI Természetföldrajzi Tanszék, Budapest

mari.laci@gmail.com 


\section{IRODALOM}

Aagesen, D. 2000: Rights to Land and Resources in Argentina's Alerces National Park. - Bulletin of Latin American Research 19. 4. pp. 547-569.

Anderson, M.K.-BArbour, M.G. 2003: Simulated Indigenous Management: A New Model for Ecological Restoration in National Parks. - Ecological Restoration 21. 4. pp. 269-277.

A.M.I. 1878: Az éjszak-amerikai Egyesült-Államok „,nagy nemzeti park”-ja. - Földrajzi Közlemények 6. pp. 202-209; 238-247.

BeAtTy, R. O. 1952: The Conservation Movement. The Annals of the American Academy of Political and Social Science, Vol. 281, TheFuture of Our Natural Resources (May, 1952), pp. 10-19.

Berki M. 2015: A térbeliség trialektikája. - Tér és Társadalom 29. 2. 3-18.

BERKi M. 2017: A földrajzi lépték változó értelmezése és a cselekvőhálózat-elmélet. - Földrajzi Közlemények 141. 3. pp. 203-215.

Bishop, K.-Dudley, N.-Phillips, A.-Stolton, S. 2004. Speaking a Common Language: The Uses and Performance of the IUCN System of Management Categories for Protected Areas. Cardiff, UK: Cardiff Univ., IUCN, UNEP-WCMC. $191 \mathrm{p}$.

CArruthers, J. 1989: Creating a National Park, 1910 to 1926. - Journal of Southern African Studies 15. 2. pp. 188-216.

Catlin, G. 1844: Letters and Notes on the Manners, Customs, and Condition of the North American Indians. - Wiley and Putnam, New York. 282 p.

Cholnoky J. 1912: Utazás az Amerikai Egyesült Államokban. - Földrajzi Közlemények 40. pp. 235 -274.

Comstock, T. B. (1874): The Yellowstone National Park. - The American Naturalist 8. 2. pp. 65-79.

CRONON, W. 1995: The Trouble with Wilderness; or, Getting Back to the Wrong Nature. - In: CRONON, W. (ed.): Uncommon Ground: Rethinking the Human Place in Nature, New York: W. W. Norton \& Co. pp. 69-90.

DERRIDA, J. 2014: Grammatológia. - Typotex, Budapest. 362 p.

DunlaP, T. R. 1999: Nature and the English diaspora: environment and history int he United States, Canada, Australia, and New Zealand. - Cambridge University Press, Cambridge. 368 p.

Eagles, P.F.J. 2002: Trends in Park Tourism: Economics, Finance and Management. - Journal of Sustainable Tourism 10.2. pp. 132-153.

ExLer Sz.-Horváth G.-Karancsi Z. 2003: Turizmus, Természetvédelem és tájhasznosítás kapcsolata egy nógrádi kistájrészlet példáján. - Földrajzi Közlemények 127. 51. 1-4. pp. 45-62.

FINE, K. 1988: The Politics of „Interpretation” at Mesa Verde National Park. - Anthropological Quarterly 61. 4. pp. 177-186.

Frost, W.-HALl. M. 2009a: Reinterpreting the creation myth: Yellowstone National Park. In: Frost, W.-HALL, M. (ed.): Tourism and Nationla Parks. - Routledge. London, N.Y. pp. 16-29.

Frost, W.-HALL. M. 2009b: American invention to international concept: the spread and evolution of national parks. In: Frost, W.-HALL, M. (ed.): Tourism and National Parks. - Routledge. London, New York pp. 30-44.

GAYNOR, A. 2017: Entangled Nature: The Stirling Range National Park. RCC Perspectives 2. - Visions of Australia: Environments in History. pp. 81-88.

GÁLOSI KovÁcs B.-HoRvÁTH G. 2018: Határokon átnyúló természetvédelmi területek lehetôségei és problémái. - Földrajzi Közlemények 142. 4. pp. 309-327.

Glendinning, M. 2003: The Conservation Movement. A Cult of the Modern Age. - Transactions of the Royal Historical Society 13. pp. 359-376.

GYöRGY A. 1881: A sziklahegység és Colorado canon-ai. - Földrajzi Közlemények 9. pp. 111-119.

HALl, M. C.-Frost, W. 2009: Introduction. The making of the nationla parks concept. - In: Frost, W.-HALL, M. (ed.): Tourism and Nationla Parks. Routledge. London, N.Y. pp. 3-15.

Hill, M. A.-PRess, A. J. 1993: Kakadu National Park: An Experiment in Partnership. - The Australian Quarterly 65. 4. pp. 23-33.

Horváth I.-Mahunka S.-Simon T.-Szujkóné LaCZA J. 1979: Nemzeti parkok kutatása - természetvédelem - tájrekonstrukció. - MTA Biológiai Osztály Közleményei 22. pp. 337-350.

HoRváth G. 2019: A földrajzi ismeretek terjesztésének új színterei: a geoparkok. - GeoMetodika 3.3.pp. 19-27.

HunFALVY J. 1874: Jelentés a földrajz körében 1873-ban tett munkálatokról. - Földrajzi Közlemények 2.pp. 1-55.

LAtour, B. 1999/1993: Sohasem voltunk modernek. - Osiris Kiadó, Budapest. 258 p.

McConnell, G. 1954: The Conservation Movement. Past and Present. - The Western Political Quarterly 7. 3. pp. 463-478.

MichaLKó G. 2005: Turizmusföldrajz és humánökológia. Kodolányi János Főiskola - MTA Földrajztudományi Kutatóintézet. Budapest - Székesfehérvár. 215 p.

Miller, P. P. 1987: Reflections on Historical Advocacy and the National Park Service. - The Public Historian 9. 2. pp. 105-113. 
Miller, Z. D. 2017: Virtual Visitors: Facebook Users and National Parks. - Journal of Park and Recreation Administration 35. 3. pp. 136-150.

Mukherjee, A. 2009: Conflict and Coexistence in a National Park. - Economic and Political Weekly 44. 23. pp. 52-59.

NASH, R. 1970/2014: Wilderness and the American mind. - Yale Univeristy Press, New Haven and London. 409 p.

Pessis, A-M.-Guidón, N. 2007: Serra da Capivara National Park, Brazil: Cultural Heritage and Society. - World Archaeology. 39. 3. pp. 406-416

PuHAKKA, R. 2008: Increasing role of tourism in Finnish national parks. - Fennia 186. 1. pp. 47-58.

RAPAICs R. 1931: A természetvédelem ügye Magyarországon. - Magyar Szemle 13. pp. 342-347.

Rövid közlemények 1900: Földrajzi Közlemények 28. 1-4. p. 143.

Rövid Közlemények 1901: Földrajzi Közlemények 29. 1-4. pp. 394-395.

SABO, H.M. 2012: ecotourism in Rodna Mountains National Park. - Research Journal of Agricultural Science 44. 2. pp. 226-232.

SAID, E. W. 2000: Orientalizmus. - Európa Könyvkiadó, Budapest. 672 p.

SchneIDER-HeCtor, D. 2014: Forging a National Park Service: „The Necessity for Cooperation”. - Journal of the Southwest 56. 4. pp. 643-682.

Schwartz, K. Z. S. 2006: „Masters in Our Native Place”: The politics of Latvian national parks on the road from Communism to „Europe”. - Political Geography 25. pp. 42-71.

SZALAi K.-SzILÁGYi Zs. 2007: A táj a turizmus fókuszában. - Földrajzi Közlemények 131. 3. pp. 147-156.

Thoreau, H.D. 1854: Walden. A polgári engedetlenség iránti kötelességről. - Fekete Sas, Budapest. 2015.288 p.

Turner, R. W. 2000: Managing Multiple Activities in a National Park. - Land Economics 76. 3. pp. $474-485$.

WAllsten, P. 2003: The „Inside-Out” Process: A Key Approach for Establishing Fulufjället National Park in Sweden. - Mountain Research and Development 23. 3. pp. 227-229.

Waugh, F. A. 1918: A National Park Policy. - The Scientific Monthly 6. 4. pp. 305-331.

West, P.-Igoe, J.-Brockington, D. 2006: Parks and Peoples: The Social Impact of Protected Areas. - Annual Review of Anthropology 35. pp. 251-277.

Wilkinson, P.F. 2003: Ecological Integrity, Visitor Use, and Marketing of Canada's National Parks. - Journal of Park and Recreation Administration 21. 32. pp. 63-83.

Wilshusen, P.-Brechin, S.R.-Fortwangler, C.-West, P. C. 2002: Reinventing a Square Wheel: a Critique of a Resurgent Protection Paradigm in International Biodiversity Conservation. - Society and Natural Resources 15. pp. 17-40.

Wyckoff, W.-DiLsAVER, L. M. 1997: Promotional Imagery of Glacier National Park. - Geographical Review 87 1. pp. 1-26. 